\title{
Relevansi Nilai-Nilai Karakter dalam Film PK Karya Rajkumar Hirani Terhadap Pendidikan Islam
}

\author{
Asrori ${ }^{1}$ \\ asrori2498@student.uns.ac.id
}

\begin{abstract}
Character is a differentiator between humans and other creatures and is the ultimate goal of education. Learning about character values in the digital era is not only through verbal learning or direct examples from teachers, but can also use film as a media. The purpose of this reasearch is to describe the character values in PK films and their relevance to Islamic education. This research is descriptive qualitative research with content analysis technique. The results of this study are the discovery of some character values such as religious, honest, responsibility, hard work, pluralism, helping others. These values have relevance to the values of I'tiqadiyyah or llahiyah and values of Khuluqiyyah or Insaniyah in Islamic education.
\end{abstract}

Keywords: $\quad$ Character Values, PK Film, Relevance of Islamic Education

Abstrak: $\quad$ Karakter adalah pembeda anatara manusia dengan makhuk lain dan merupakan tujuan akhir dari pendidikan. Pembelajaran mengenai nilai-nilai karakter di era digital ini tidak lagi hanya sebatas melalui ceramah atau teladan langsung dari pendidik, namun juga dapat menggunakan film sebagai media pembelajaran. Tujuan penelitian ini adalah menjabarkan nilai-nilai karakter dalam film PK serta relevansinya dengan pendidikan Islam. Metode yang digunakan adalah kualitatif deskriptif dengan teknik analisis kajian isi. Hasil dari penelitian ini adalah ditemukannya beberapa nilai karakter seperti religius, jujur, tanggung jawab, kerja keras, pluralis, dan suka menolong yang dimana nilai-nilai tersebut memiliki relevansi dengan nilai l'tiqadiyah atau llahiyyah dan nilai Khuluqiyyah atau Insaniyah dalam pendidikan Islam.

Kata Kunci: $\quad$ Nilai-Nilai Karakter, Film PK, Relevansi Pendidikan Islam

Submitted: Oktober $2019 \quad$ Reviewed: Oktober $2019 \quad$ Accepted: Februari $2020 \quad$ Published: Maret 2020

1Teknologi Pendidikan, Universitas Sebelas Maret 


\section{PENDAHULUAN}

K

emajuan suatu bangsa tidak didapat hanya melalui sumber daya alam yang melimpah, ada satu hal lain yang menjadi faktor penentu dalam kemajuan suatu bangsa yaitu karakter yang dimiliki bangsa tersebut. Istilah 'karakter' berasal dari istilah Yunani charassein yang berarti membuat tajam atau membuat dalam, selain itu juga memiliki arti mengukir (Kuriniawan, 2017). Maslich (2018) mengemukakan bahwa karakter itu memiliki kaitan dengan kekuatan moral, bermakna positif, bukan netral hingga kemudian diasumsikan bahwa orang berkarakter adalah orang yang memiliki kualitas moral yang positif. Riyaningsih, dkk (2018) menjelaskan bahwa karakter adalah watak, sikap, perilaku yang tampak dari seseorang yang menjadi pembeda antara satu orang dengan orang lainnya. Karakter adalah sebuah kecenderungan perilaku yang konsisten namun bisa berubah. Maka dari itu, perlu ada sarana untuk membentuk dan membangun karakter yang baik melalui pendidikan. Pembentukan karakter merupakan tujuan utama dalam pendidikan. Pernyataan tersebut senada dengan yang dikemukakan oleh Socrates bahwa tujuan dasar dari pendidikan adalah untuk menjadikan seseorang good and smart. Nabi Muhammad Saw, bahkan dalam haditsnya dengan jelas menyatakan bahwa tujuannya diutus sebagai nabi dan rasul adalah untuk menyempurnakan akhlak dan membentuk karakter yang baik (Majid \& Andayani, 2017).

Setiap negara yang mencapai keberhasilan pasti memiliki karakter baik sebagai modal utama dalam meraih keberhasilan tersebut. Tiongkok misalnya, pada era 70-an, Tiongkok dapat dikatakan tidak lebih makmur dari Indonesia, namun saat ini Tiongkok menjadi salah satu negara pengekspor terbesar. Pencapaian tersebut didasarkan pada karakter disiplin dan kerja keras yang dimiliki oleh negara tersebut. Selain itu, ada negara India yang dimana mereka memiliki sebuah karakter atau budaya yang disebut Swadeshi, yaitu sebuah karakter untuk maju dan membangun dengan kemampuan sendiri. Budaya tersebut membuat ketergantungan India terhadap impor sangat rendah dan menjadikannya sebagai negara yang paling mandiri di Asia saat ini (Muslich, 2018). Karakter sebagai salah satu komponen penting pembangunan bangsa Indonesia sebenarnya telah ada sejak kemerdekaan bangsa ini pada tanggal 17 Agustus 1945. Presiden Soekarno menegaskan nation and character building sangat diperlukan sebagai bagian tidak terpisahkan dari pembangunan bangsa Indonesia (Masnur, 2018). Presiden Soekarno sangat menyadari bahwa pembentukan karakter yang kemudian menghasilkan karakter bangsa yang kuat adalah kunci dari keberhasilan dan kelanggengan suatu bangsa.

Dewasa ini, karakter bangsa tengah mengalami kemorosotan. Kita dapat melihat meningkatnya tindak kriminal, penyalahgunaan narkoba, seks bebas, aksi bullying, rasisme, penyebaran hoaks atau berita bohong, dan semakin turunnya tingkat toleransi. Oleh karena itu penguatan akan pentingnya karakter atau pendidikan karakter harus semakin didengungkan dan prakteknya harus lebih gencar dilaksanakan. Pelaksanaan pendidikan karakter tidak hanya dapat dilakukan di lembaga pendidikan formal saja namun sebaiknya juga dilakukan di lingkungan masyarakat bahkan keluarga. Penguatan nilai-nilai karakter peserta didik juga tidak hanya dilakukan dengan pembelajaran klasikal melalui ceramah guru, buku pelajaran, atau peneladanan langsung siswa terhadap guru tersebut, namun juga dapat menggunakan alternatif media pembelajaran lain. Media pembelajaran menurut Rohmat (2016) adalah sesuatu yang bisa digunakan untuk menyampaikan pesan, merangsang pikiran, minat, perhatian dan perasaan yang dapat membuat penerimaan pesan menjadi lebih jelas sehingga membuat peserta didik mendapatkan pengalaman belajar serta perubahan perilaku atau kompetensi. Sejalan dengan itu, Suryani, dkk (2018) menyatakan bahwa media pembelajaran adalah segala bentuk maupun sarana yang digunakan sebagai pembawa informasi yang dibuat serta dipergunakan berdasarkan teori pembelajaran, dapat digunakan guna mencapai tujuan pembelajaran dalam menyalurkan pesan, merangsang pikiran, perasaan, perhatian, dan kemauan peserta didik sehingga dapat mendukung terjadinya proses belajar yang disengaja, memiliki tujuan, dan terkendali. Film 
adalah salah satu alternatif media tersebut. Penggunaan film selain dapat menarik perhatian siswa, diharapkan juga dapat membuat peserta didik mampu menarik pesan yang hendak disampaikan dan memperluas wawasan berpikir peserta didik.

Film adalah salah satu media komunikasi yang efektif untuk hiburan sekaligus dapat digunakan sebagai penyampai pesan guna mempengaruhi sikap, pola pikir dan membuka wawasan para penikmatnya (Widyatmaka, dkk., 2019). Seorang penonton film dapat melihat imajinasi dari orang lain dalam hal ini film-maker secara jelas melalui media audio visual. Pratista dalam Widyatmaka, dkk. (2019) menyatakan bahwa secara umum terdapat dua unsur yang membentuk film yaitu unsur naratif dan unsur sinematik. Unsur sinematik meliputi berbagai aspek teknis dalam sebuah film, unsur sinematik terbagi menjadi empat elemen pokok yakni, mise-en-scene, sinematografi, editing, dan suara. Sementara itu, unsur naratif merupakan unsur yang berhubungan dengan aspek cerita dalam sebuah film, unsur naratif adalah suatu rangkaian peristiwa dalam film yang memilki hubungan sebab akibat yang terjadi dalam suatu ruang dan waktu.

Terdapat beberapa penelitian yang membahas penggunaan film sebagai media dalam pengembangan karakter di antaranya tulisan dari Hidayatulloh (2017) yang berisi tentang nilai-nilai pendidikan karakter untuk anak usia dini dalam film Adit \& Sopo Jarwo. Penelitian tersebut menghasilkan kesimpulan bahwa dalam film Adit \& Sopo Jarwo terkandung nilai-nilai karakter seperti religius, kerja keras, mandiri, bersahabat dan komunikatif, jujur, peduli sosial, kreatif, menghargai prestasi, dan tanggung jawab. Berikutnya penelitian dari Wibowo (2018) yang membahas nilai pendidikan karakter dalam film Kungfu Panda dan relevansinya dengan pendidikan agama Islam. Penelitian tersebut berkesimpulan bahwa dalam film Kungfu Panda terdapat beberapa nilai-nilai karakter yang juga memiliki relevansi dengan pendidikan agama Islam. Selanjutnya, penelitian dari Wegig Widiyatmaka, dkk. yang membahas mengenai nilai pendidikan karakter pada film Sang Kiai (2019). Penelitian tersebut memberi kesimpulan bahwa dalam film Sang Kiai terdapat nilai-nilai pendidikan karakter yang relevan sebagai nilai-nilai pembangunan karakter dan film tersebut dapat digunakan sebagai media pembelajaran pembentukan karakter.

Penelitian ini bertujuan untuk mendeskripsikan nilai-nilai karakter yang terdapat dalam film PK karya Rajkumar Hirani yang diproduksi oleh Vinud Chopra Films dan Rajkumar Hirani Films dan menemukan relevansinya dengan pendidikan Islam. Penelitian mengenai nilai-nilai karakter dalam media film sudah pernah dilakukan sebelumnya sebagaimana penulis sebutkan di atas. Namun, pada penelitian ini, objek yang dikaji yaitu film PK menggambarkan alur cerita yang berbeda dengan kebanyakan film lain. Film ini bergenre komedi satire dan bercerita mengenai pencarian Tuhan yang dilakukan oleh seorang alien di tengah keberagaman agama yang ada di negara India. Latar tempat dan alur cerita film ini sangat tepat untuk mengambil pelajaran tentang bagaimana karakter-karakter yang diperlukan untuk menghadapi keberagaman dalam kehidupan berbangsa dan beragama. Oleh karena itu, penulis tertarik untuk mengkaji nilai-nilai karakter yang terdapat pada film tersebut, kemudian melihat relevansinya dengan pendidikan Islam.

\section{METODE PENELITIAN}

Penelitian ini adalah jenis penelitian deskriptif kualitatif. Penelitian deskriptif sebagaimana dikemukakan oleh Sukmadinata (2012) adalah jenis penelitian yang paling dasar. Jenis penelitian ini bertujuan untuk mendeskripsikan atau menggambarkan fenomena-fenomena yang ada, baik fenomena yang terjadi secara alamiah maupun fenomena yang terjadi karena rencana manusia. Penelitian ini berisi kajian tentang aktivitas, karakteristik, hubungan, perubahan, kesamaan, dan perbedaannya dengan fenomena-fenomena lain. Sesuai definisi tersebut, maka penelitian ini menggambarkan mengenai nilai-nilai karakter yang terdapat dalam film $P K$. 
Teknik pengumpulan data yang digunakan adalah teknik dokumentasi yaitu dokumentasi film PK dan dokumen-dokumen atau literatur-literatur yang berhubungan dengan nilai-nilai karakter. Selain itu juga digunakan teknik observasi yaitu mengamati tayangan film PK. Selanjutnya menyeleksi dialog dan adegan yang mengandung nilai-nilai karakter di dalamnya. Berikutnya peneliti menganalisis serta mendeskripsikan nilai-nilai tersebut berdasarkan teori-teori yang diperoleh dari literatur-literatur yang berhubungan dengan nilai-nilai karakter menggunakan teknik content analysis/kajian isi. Content analysis digunakan untuk menganalisis nilai-nilai karakter yang terdapat dalam monolog, dialog, serta narasi dari adegan yang ada pada film PK karya Rajkumar Hirani. Kemudian penulis melihat relevansi antarai nilai-nilai tersebut dengan pendidikan Islam.

\section{HASIL DAN PEMBAHASAN}

\section{Nilai-Nilai Karakter}

Hermawan Kertajaya dalam Majid \& Andayani (2017) mendefinisikan karakter sebagai ciri khas yang dimiliki oleh seorang individu. Ciri khas tersebut adalah asli dan mengakar pada kepribadian benda atau individu tersebut dan merupakan mesin pendorong untuk seseorang dalam bertindak, bersikap, berujar, dan merespon sesuatu. Kurniawan, (2017) menyatakan bahwa karakter seseorang terbentuk karena kebiasaan yang dilakukan, sikap yang diambil dalam menghadapi suatu keadaan, dan kata-kata yang diucapkan kepada orang lain di sekitarnya. Karakter tersebut kemudian menjadi sesuatu yang merekat pada diri seseorang dan biasanya orang tersebut tidak menyadari karakter yang ia miliki. Samani \& Hariyanto (2017) memaknai karakter sebagai cara berpikir serta berperilaku yang khas untuk hidup dan bekerja sama, baik dalam lingkup keluarga hingga bernegara. Setiap perilaku, sikap, cara berpikir seseorang dalam kajian karakter kemudian disebut nilai-nilai karakter.

Nilai yang benar dan diterima secara universal sebagaimana dijelaskan oleh Richard Eyre \& Linda adalah nialai yang menghasil perilaku positif dan perilaku tersebur memiliki dampak positif untuk orang yang menjalankan maupun untuk orang lain. Selanjutnya Richard menerangkan bahwa nilai adalah suatu kualitas yang dibedakan menurut: a) kemampuannya untuk berlipat ganda atau bertambah meskipun diberikan kepada orang lain dan b) kenyataan bahwa semakin banyak nilai yang diberikan kepada orang lain, maka semakin banyak pula nilai serupa yang diterima dari orang lain (Majid \& Andayani, 2017).

Sementara itu, istilah 'karakter' berasal dari istilah Yunani charassein yang berarti membuat tajam atau membuat dalam, selain itu juga memiliki arti mengukir (Kuriniawan, 2017). Maslich (2018) mengemukakan bahwa karakter itu memiliki kaitan dengan kekuatan moral, bermakna positif, bukan netral hingga kemudian diasumsikan bahwa orang berkarakter adalah orang yang memiliki kualitas moral yang positif. Riyaningsih, dkk (2018) menjelaskan bahwa karakter adalah watak, sikap, perilaku yang tampak dari seseorang yang menjadi pembeda antara satu orang dengan orang lainnya. Karakter adalah sebuah kecenderungan perilaku yang konsisten namun bisa berubah. Maka dari itu, perlu ada sarana untuk membentuk dan membangun karakter yang baik melalui pendidikan.

Terdapat begitu banyak pengelompokan butir-butir nilai karakter, namun pada penelitian ini penulis mengutip pengelompokan butir-butir nilai karakter sebagaimana dikemukakan Mohamad Mustari dalam bukunya Nilai Karakter Refleksi untuk Pendidikan (2014) yang mengemukakan 25 nilai karakter sebagai berikut:

Tabel 1. Nilai Karakter

\begin{tabular}{|l|l|l|}
\hline 1. & Religius & $\begin{array}{l}\text { nilai karakter dalam hubungannya dengan Tuhan. la menunjukkan } \\
\text { bahwa pikiran, perkataan, dan tindakan seseorang yang } \\
\text { diupayakan selalu berdasarkan pada nilai-nilai Ketuhanan dan/ } \\
\text { atau ajaran agamanya. }\end{array}$ \\
\hline
\end{tabular}




\begin{tabular}{|c|c|c|}
\hline 2. & Jujur & $\begin{array}{l}\text { perilaku yang didasarkan pada upaya menjadikan dirinya sebagai } \\
\text { orang yang selalu dapat dipercaya dalam perkataan, tindakan, dan } \\
\text { pekerjaan, baik terhadap diri sendiri maupun terhadap pihak lain. }\end{array}$ \\
\hline 3. & Bertanggung jawab & $\begin{array}{l}\text { sikap dan perilaku seseorang untuk melaksanakan tugas dan } \\
\text { kewajibannya sebagaimana yang seharusnya dia lakukan, } \\
\text { terhadap diri sendiri, masyarakat, lingkungan (alam, sosial, dan } \\
\text { budaya), negara dan Tuhan. }\end{array}$ \\
\hline 4. & Bergaya hidup sehat & $\begin{array}{l}\text { segala upaya untuk menerapkan kebiasaan yang baik dalam } \\
\text { menciptakan hidup yang sehat dan menghindarkan kebiasaan } \\
\text { buruk yang dapat mengganggu kesehatan. }\end{array}$ \\
\hline 5. & Disiplin & $\begin{array}{l}\text { tindakan yang menunjukkan perilaku tertib dan patuh pada } \\
\text { berbagai ketentuan dan peraturan. }\end{array}$ \\
\hline 6. & Kerja keras & $\begin{array}{l}\text { perilaku yang menunjukkan upaya sungguh-sungguh dalam } \\
\text { mengatasi berbagai hambatan guna menyelesaikan tugas } \\
\text { (belajar/pekerjaan) dengan sebaik-baiknya. }\end{array}$ \\
\hline 7. & Percaya diri & $\begin{array}{l}\text { sikap yakin akan kemampuan diri sendiri terhadap pemenuhan } \\
\text { tercapainya setiap keinginan dan harapannya. }\end{array}$ \\
\hline 8. & Berjiwa & $\begin{array}{l}\text { sikap dan perilaku yang mandiri dan pandai atau berbakat } \\
\text { mengenali produk baru, menentukan cara produksi baru, } \\
\text { menyusun operasi untuk pengadaan produk baru, } \\
\text { memasarkannya, serta mengatur permodalan operasinya. }\end{array}$ \\
\hline 9. & $\begin{array}{l}\text { Berpikir logis, kritis, } \\
\text { kreatif, dan inovatif }\end{array}$ & $\begin{array}{l}\text { berpikir dan melakukan sesuatu secara kenyataan atau logis untuk } \\
\text { menghasilkan cara atau hasil baru dan termutakhir dari apa yang } \\
\text { telah dimiliki. }\end{array}$ \\
\hline 10. & landiri & $\begin{array}{l}\text { sikap dan perilaku yang tidak mudah tergantung pada orang lain } \\
\text { dalam menyelesaikan tugas-tugas. }\end{array}$ \\
\hline 11. & gin tahu & $\begin{array}{l}\text { sikap dan tindakan yang selalu berupaya untuk mengetahui lebih } \\
\text { mendalam dan meluas dari apa yang dipelajarinya, dilihat, dan } \\
\text { didengar. }\end{array}$ \\
\hline 12. & Cinta ilmu & $\begin{array}{l}\text { cara berpikir, bersikap, dan berbuat yang menunjukkan kesetiaan, } \\
\text { kepedulian, dan penghargaan yang tinggi terhadap pengetahuan. }\end{array}$ \\
\hline 13. & Sadar diri & $\begin{array}{l}\text { sikap tahu dan mengerti serta melaksanakan apa yang menjadi } \\
\text { milik/hak diri sendiri dan orang lain serta tugas/kewajiban diri } \\
\text { sendiri serta orang lain. }\end{array}$ \\
\hline 14. & $\begin{array}{l}\text { Patuh pada aturan } \\
\text { sosial }\end{array}$ & $\begin{array}{l}\text { sikap menurut dan taat terhadap aturan-aturan berkenaan dengan } \\
\text { masyarakat dan kepentingan umum. }\end{array}$ \\
\hline 15. & Respek & $\begin{array}{l}\text { sikap dan tindakan yang mendorong dirinya untuk menghasilkan } \\
\text { sesuatu yang berguna bagi masyarakat, mengakui dan } \\
\text { menghormati keberhasilan orang lain. }\end{array}$ \\
\hline 16. & Santun & $\begin{array}{l}\text { sifat yang halus dan baik dari sudut pandang tata bahasa maupun } \\
\text { tata perilakunya ke semua orang. }\end{array}$ \\
\hline 17. & Demokratis & $\begin{array}{l}\text { cara berpikir, bersikap, dan bertindak yang menilai sama hak dan } \\
\text { kewajiban dirinya dan orang lain. }\end{array}$ \\
\hline 18. & Ekologis & $\begin{array}{l}\text { sikap dan tindakan yang selalu berupaya mencegah kerusakan } \\
\text { pada lingkungan alam di sekitarnya, dan mengembangkan upaya- } \\
\text { upaya untuk memperbaiki kerusakan alam yang sudah terjadi dan } \\
\text { selalu ingin memberi bantuan bagi orang lain dan masyarakat yang } \\
\text { membutuhkan. }\end{array}$ \\
\hline 19. & Nasionalis & cara berpikir, bersikap, dan berbuat yang menunjukkan kesetiaan, \\
\hline
\end{tabular}




\begin{tabular}{|l|l|l|}
\hline & & $\begin{array}{l}\text { kepedulian, dan penghargaan yang tinggi terhadap bahasa, } \\
\text { lingkungan fisik, sosial, budaya, ekonomi, dan politik bangsanya. }\end{array}$ \\
\hline 20. & Pluralis & $\begin{array}{l}\text { sikap memberikan respek/hormat terhadap berbagai perbedaan } \\
\text { yang ada di masyarakat baik yang berbentuk fisik, sifat, adat, } \\
\text { budaya, suku, dan agama. }\end{array}$ \\
\hline 21. & Cerdas & $\begin{array}{l}\text { kemampuan seseorang dalam melakukan suatu tugas secara } \\
\text { cermat, tepat, dan cepat. }\end{array}$ \\
\hline 22. & Suka menolong & sikap dan tindakan yang selalu berupaya membantu orang lain. \\
\hline 23. & Tangguh & $\begin{array}{l}\text { sikap dan perilaku pantang menyerah atau tidak pernah putus asa } \\
\text { ketika menghadapi berbagai kesulitan dalam melaksanakan } \\
\text { kegiatan atau tugas sehingga mampu mengatasi kesulitan tersebut } \\
\text { dalam mencapai tujuan. }\end{array}$ \\
\hline 24. & $\begin{array}{l}\text { Berani } \\
\text { resiko mengambil }\end{array}$ & $\begin{array}{l}\text { kesiapan menerima risiko/akibat yang mungkin timbul dari tindakan } \\
\text { nyata. }\end{array}$ \\
\hline 25. & Berorientasi tindakan & $\begin{array}{l}\text { sikap yang membuat hidup lebih bersifat praktis, nyata, dan tidak } \\
\text { terjebak ke dalam lamunan dan pemikiranyang tidak-tidak. }\end{array}$ \\
\hline
\end{tabular}

\section{Film PK}

Internalisasi nilai-nilai karakter dapat menggunakan berbagai metode dan media. Salah satunya menggunakan media film. Film merupakan salah satu media komunikasi modern yang efektif untuk menghibur dan menyampaikan pesan yang dapat mempengaruhi sikap para penontonnya. Film memiliki banyak peran, selain sebagai sarana hiburan, film juga memiliki fungsi informatif, edukatif, bahkan persuasif. Tayangan-tanyangan dalam film ikut mempengaruhi para penikmatnya, hal tersebut dapat terlihat dari banyaknya orang yang mengikuti cara berpakaian, cara berpakaian, bahkan gaya hidup sehari-hari (Widyatmaka, dkk, 2019). Penulis pada penelitian ini mengambil film berjudul PK sebagai objek yang akan diteliti mengenai nilai-nilai karakter yang terkandung di dalamnya.

Film PK (Peekay) adalah sebuah film drama komedi satir India yang tayang perdana pada tahun 2014. Judul PK merupakan ejaan Inggris untuk sebutan bahasa Hindi "Peekay" yang berarti "mabuk". Film ini diproduksi oleh Vinud Chopra Films dan Rajkumar Hirani Films dan disutradarai oleh Rajkumar Hirani serta ditulis oleh Hirani dan Abhijat Joshi. Film ini termasuk film India paling sukses sepanjang masa dengan peringkat ke-66 tertinggi dalam film terlaris tahun 2014.

Film ini bercerita tentang sesosok alien humanoid (Aamir Khan) yang mendarat di bumi untuk misi penelitian di Rajasthan, India. Namun, alien tersebut terdampar ketika pemancar atau remot kontrol untuk memanggil pesawat ruang angkasa berupa sebuah liontin di lehernya dicuri. Alien tersebut menyadari kebiasaan bumi, belajar untuk menyesuaikan diri antara manusia dengan mengenakan pakaian dan menggunakan uang yang ia curi dari pasangan yang sedang berhubungan seks di "mobil bergoyang". la mencoba untuk belajar untuk berkomunikasi dengan memegang tangan penduduk dan menyerap pengetahuan yang ada dalam pikiran mereka melalui sentuhan tangan, tapi mereka mengejarnya ketika ia melakukan hal tersebut karena mereka mengira ia sebagai seorang cabul. Suatu hari, Bhairon Singh (Sanjay Dutt) menabrak si alien dan membuatnya sempat tidak sadarkan diri. Bhairon membawanya ke dokter yang menyatakan si alien adalah seseorang yang menderita amnesia. Bhairon mengasumsikan amnesia si alien sebagai akibat dari tabrakan dengan kendaraannya. Bhairon sekarang tahu bahwa korban kecelakaan itu tidak akan dapat mengeluh tentang kecelakaan yang dialami. Jadi Bhairon memutuskan untuk melarikan diri. Kemudian, ia merasa kasihan, berubah pikiran dan mengajak si alien bersama dengan kelompoknya. Seiring dengan waktu, si alien menjadi temannya. Kemudian, ia menafsirkan bahwa kelakuan si alien yang ingin memegang tangan perempuan adalah keinginan seksual, dan membawanya ke rumah prostitusi. Di sana, si alien 
memegang tangan seorang pekerja seks komersial selama enam jam dan dengan demikian ia bisa belajar bahasa Bhojpuri.

Alien melakukan perjalanan ke Delhi untuk mencari remote yang dicuri. Karena tingkah lakunya yang aneh, orang-orang di kota menganggap dia mabuk (mabuk diterjemahkan pee-kay dalam bahasa Hindi) dan memanggilnya PK atau Peekay. Delhi ternyata adalah kota yang sangat besar, dan orangorang mengatakan kepadanya bahwa hanya Tuhan yang dapat membantu dia menemukan remotnya. Peekay mencoba untuk menemukan Tuhan, tetapi bingung dengan berbagai agama dan tradisi yang beragam di India. Dia kemudian menemukan bahwa remot miliknya ada pada pemimpin spiritual salah satu agama di India, Tapasvi Maharaj (Saurabh Shukla). Namun, Tapasvi secara palsu mengklaim remot Peekay sebagai benda dari Tuhan yang ia dapat di Himalaya dan menolak untuk mengembalikannya ke Peekay. Peekay bingung dan menyimpulkan bahwa Tapasvi serta pemuka agama lainnya mengalami "salah sambung" kepada Tuhan dan sebagai hasilnya berarti menyebarkan kesalahpahaman ritual.

Sementara itu di Bruges, Jaggu (Anushka Sharma) jatuh cinta dengan seorang pria bernama Sarfaraz (Sushant Singh Rajput). Ayah Jaggu (Parikesit Sahni) tidak menyukai hubungan mereka karena Sarfaraz adalah seorang Muslim dari Pakistan, ia kemudian berkonsultasi dengan Tapasvi yang meramalkan bahwa Sarfaraz akan mengkhianati Jaggu. Bertekad untuk membuktikan bahwa mereka salah, Jaggu mengajak Sarfaraz menikah keesokan harinya. Namun pada hari pernikahan sebuah masalah terjadi dan pernikahan pun tidak terlaksana. Dia kembali ke India di mana ia menjadi reporter televisi. Jaggu kemudian tertarik saat melihat Peekay membagikan selebaran tentang "menghilangnya" Tuhan. Setelah mendengar Peekay, Jaggu membuat rencana untuk mengekspos Tapasvi dan mengembalikan remote Peekay yang diklaim oleh Tapasvi.

Jaggu mendorong ribuan orang untuk mengirimkan video dari pengalaman mereka sendiri dengan kepala agama, menyebut mereka dengan istilah "salah sambung". Sementara itu, dari kontak Peekay dengan Bhairon Singh mengatakan bahwa ia akan datang ke Delhi pada hari berikutnya membawa orang yang telah mencuri remot Peekay, namun ia tewas dalam ledakan bom di stasiun kereta api sesaat setelah tiba di Delhi. Teroris telah menanam bom sebagai pembalasan atas protes "salah sambung" yang dibuat oleh Peekay. Akhirnya, Tapasvi datang ke studio dan menghadapi Peekay secara live. Tapasvi mengklaim ia memiliki hubungan langsung dengan Tuhan dan mengacu pada ramalan pengkhianatan Sarfaraz sebagai bukti. Namun, Peekay, yang sebelumnya menyerap kenangan Jaggu, menemukan bahwa Sarfaraz tidak menulis surat yang ia terima. Jaggu kemudian menghubungi Kedutaan Besar Pakistan di Belgia di mana Sarfaraz permah bekerja paruh waktu di tempat tersebut, pihak kedutaan mengatakan kepadanya bahwa Sarfaraz masih mencintainya dan menyebut bahwa setiap hari Sarfaraz menelpon kedutaan dan menanyakan apakah Jaggu menelponnya. Jaggu dan Sarfaraz pada akhirnya terhubung kembali berkat Peekay dan ramalan Tapasvi terungkap sebagai penipuan, ia dipaksa untuk mengembalikan remot Peekay.

Peekay ternyata secara diam-diam telah jatuh cinta dengan Jaggu tetapi menahan diri untuk mengatakannya karena dia mengetahui bahwa Jaggu mencintai Sarfaraz. Dia kemudian merekam suara Jaggu dan mengisi kopernya dengan baterai sehingga ia bisa mendengarkan kaset yang berisi rekaman suara Jaggu di planet asalnya. Sementara ketika akan berangkat pulang, dia berbohong kepada Jaggu mengenai isi dari kaset tersebut, meskipun akhirnya Jaggu mengetahui kebenarannya. Jaggu kemudian menulis buku tentang kisah Peekay untuk mengenangnya.

\section{Nilai-Nilai Karakter dalam Film PK}

Film PK mengandung beberapa nilai karakter di dalamnya. Penulis menggunakan dua puluh lima butir nilai karakter yang dikemukakan oleh Mohamad Mustari dengan mengamati tayangan film berupa 
dialog dan adegan yang ada di dalamnya sehingga didapatkan nilai-nilai karakter dalam film PK sebagaimana berikut:

\section{a. Religius}

Mustari (2014) meneyebut bahwa sebenarnya di dalam jiwa manusia sudah terdapat benih keyakinan yang bisa merasakan akan eksistensi Tuhan. Rasa semacam itu sudah merupakan fitrah (naluri insani) yang kemudian disebut sebagai naluri keagamaan. Stark \& Glock dalam Mustari (2014) mengemukan lima unsur yang dapat mengembangkan seseorang menjadi beragama atau religius, yaitu keyakinan agama, ibadat, pengetahuan agama, pengalaman agama, dan konsekuensi dari keempat unsur tersebut.

Peekay sebagai karakter utama dalam film ini pada dasarnya menunjukkan nilai religius dan unsur-unsur yang dikemukakan oleh Stark \& Glock di atas, meskipun hal tersebut dicapai oleh Peekay secara bertahap.

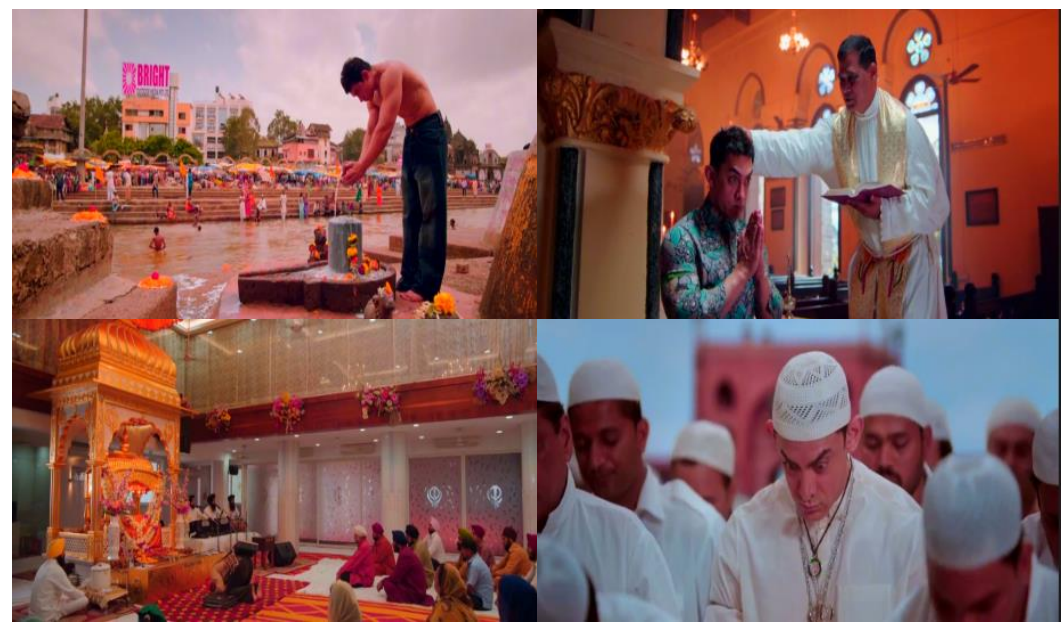

Gambar 1. PK melaksanakan berbagai ritual ibadah agama yang ada di India

Pada gambar di atas yang di dapat melalui cuplikan tayangan film PK terlihat bagaimana Peekay mengamalkan ritual ibadah berbagai agama yang ada di India. la melakukan hal tersebut dengan maksud untuk menemukan Tuhan yang sesungguhnya yang dapat membantunya untuk menemukan remotnya kembali. Jika kita melihat secara tidak kontekstual, apa yang dilakukan oleh Peekay adalah sebuah kesalahan. Namun ketika penulis mengamati lebih jauh, pada tahap ini Peekay memang belum sepenuhnya memahami tentang apa itu agama. Peekay baru sepenuhnya paham mengenai Tuhan dan agama menjelang akhir cerita. Menjelang akhir cerita, Peekay dan tuan Tapasvi berdebat dalam sebuah acara TV. Pada saat itu, Peekay sudah mengetahui bahwa Tapasvi selama ini berbohong, ia mengaku bisa berkomunikasi langsung kepada Tuhan dan juga berbohong mengenai remot kontrol Peekay yang ia klaim sebagai pemberian Tuhan. Berikut salah satu pernyataan Peekay dalam acara TV tersebut:

"Kau benar sekali tuan Tapasvi, ada satu masa saat aku juga tak bisa mencari makanan untuk dimakan, aku tak punya tempat tinggal,, aku sering menangis, aku bahkan tak punya teman, aku hanya punya satu hal, Tuhan. Setiap hari aku berpikir hari esok akan lebih baik, Tuhan akan memberikanku jalan keluar, Aku setuju bahwa dengan percaya pada Tuhan seseorang punya harapan, kesulitan akan pergi, keberanian akan bangkit, akan ada kekuatan. Tapi aku punya satu pertanyaan, Tuhan mana yang harus aku percayai? Tuhan yang menciptakan kita semua? Atau Tuhan yang dicipktakan oleh orang sepertimu? Kita tidak tahu tentang Tuhan yang menciptakan kita semua, tapi Tuhan ciptaanmu itu sama sepertimu, pembohong, berpura-pura, memberi harapan palsu, 


\section{TEKNODIKA}

e-ISSN: 2656-6621

http://jurnal.uns.ac.id/Teknodika

menghormati orang kaya, mengabaikan orang miskin, bahagia saat dipuji, orang-orang bahkan takut bersuara. Pesanku sangat sederhana, Tuhan yang menciptakan kita semua, percayalah padanya. Sementara Tuhan cipataamu, duplikasi Tuhan, musnahkanlah."

Pada ungkapan Peekay di atas, terlihat bahwa Peekay sangat meyakini tentang eksistensi Tuhan. la bahkan mengungkapkan bahwa ada satu duplikasi Tuhan yang diciptakan oleh sekelompok manusia untuk memperdaya manusia lain. Dalam hal ini, pernyataan Peekay tidak mengacu pada agama tertentu namun lebih mengarah kepada oknum-oknum pemuka agama yang membawa nama Tuhan sebagai alat untuk menghasilkan keuntungan bagi diri mereka sendiri, seperti apa yang dilakukan oleh Tapasvi. Ketokohan dalam agama yang Tapasvi milki ia gunakan untuk memperkaya dirinya sendiri dengan memanfaatkan umatnya. Tidak hanya itu, dalam kelanjutan pernyataannya, Peekay mengungkapkan bahwa nama Tuhan juga digunakan untuk membenci, menyakiti, bahkan membunuh manusia lain, seperti yang dialami oleh teman Peekay, Bhairon Singh yang tewas terbunuh oleh serangan bom teroris di stasiun kereta saat hendak membawa pencuri yang mencuri dan menjual remot kontrol Peekay kepada Tapasvi.

Berdasarkan data dan analisis di atas, penulis berkesimpulan bahwa Peekay memiliki nilai religius dalam dirinya, terbukti dengan dirinya yang masih meyakini eksistensi Tuhan, meskipun selama ini berbagai macam ibadah yang ia lakukan tidak langsung membantunya mendapatkan remot kontrol yang ia cari.

\section{b. Jujur}

Jujur merujuk pada suatu karakter moral yang memiliki sidat-sifat positif dan mulia seperti integritas, penuh kebenaran, lurus, sekaligus tiadanya bohong, curang, ataupun mencuri (Mohamad Mustari, 2014: 12). Nilai kejujuran atau tidak berbohong terlihat ketika Peekay dan Jaggu berdebat.

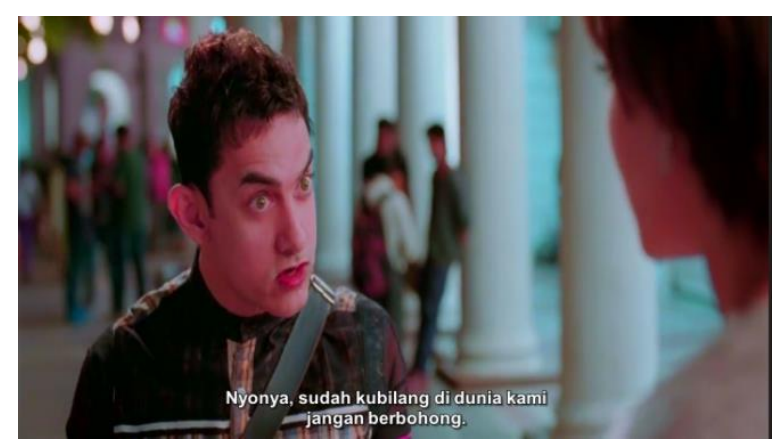

Gambar 2. Peekay berdebat dengan Jaggu tentang kebenaran semua ceritanya

Jaggu tidak mempercayai seluruh cerita Peekay yang menjelaskan bahwa ia adalah seorang alien dari luar bumi yang sedang kehilangan remot kontrol dan tidak bisa kembali ke planet asalnya dan Peekay memiliki satu hal unik yang memang menjadi cara komunikasi makhluk sejenisnya. la berkomunikasi tidak menggunakan bahasa atau lisan, melainkan melalui perasaan dengan cara menyentuh tangan orang yang diajak berkomunikasi. Selanjutnya, ketika mereka tengah berdebat ada seorang lelaki tua yang menyentuh tangan Peekay. Lelaki tersebut meminta uang kepada Peekay karena istrinya sedang sakit. Melihat kejadian tersebut Jaggu semakin yakin kalau Peekay berbohong kepadanya karena ia mengetahui bahwa di sekitar tempat itu tidak ada rumah sakit. Peekay kemudian menjelaskan bahwa ia mengetahui hal tersebut. la juga mengetahui bahwa kakek tersebut meminta uang karena ingin membahagiakan istrinya yang sedang berulang tahun. Kakek tersebut mengumpulkan uang pensiunnya untuk merayakan ulang tahun istrinya dengan sebuah makan malam di restoran sebuah hotel mewah, namun istrinya memesan es krim dan membuat uangnya berkurang, agar tidak membuat istrinya kecewa, sang kakek pergi untuk mencari uang tambahan. Peekay yang 
mengetahui isi hati sang kakek karena sang kakek menyentuh tangannya merasa iba dan memberikan uang kepada sang kakek bahkan ia memberikan tambahan.

Jujur merupakan kesesuaian antara berita dan kenyataan yang ada (Mustari, 2014). Hal tersebut yang disampaikan oleh Peekay kepada Jaggu, mulai dari kisah tentang dirinya hingga peristiwa sang kakek yang meminta uang tersebut. Dapat disimpulkan Peekay memiliki sifat atau nilai kejujuran di dalam dirinya.

\section{c. Tanggung Jawab}

Tanggug jawab hakikatnya adalah segala sesuatu yang menyangkut kedirian kita, siapa kita, dan mengapa kita harus berbuat ini dan itu, karena tanggung jawab berarti eksistensi seseorang (Mustari, 2014). Dalam film PK sikap tanggung jawab ditunjukkan oleh karakter Bhairon Singh, ketika ia sedang mengendari mobilnya, Peekay berlari dari persimpangan dan kemudian tertabrak oleh mobil Bairon Singh. Bairon Singh pun membawa Peekay ke dokter, di klinik, dokter mendiagnosis bahwa Peekay mengalami hilang ingatan. Bhairon pada awalnya ingin melarikan diri dan meninggalkan Peekay di klinik tersebut, namun pada akhirnya ia membawa Peekay ke rumahnya dan berupaya untuk mengembalikan ingatan Peekay, walaupun sebenarnya Peekay tidak mengalami hilang ingatan. Namun kemudian berkat jasa Bhairon lah, Peekay dapat memahami bahasa dan berbicara seperti orang-orang.

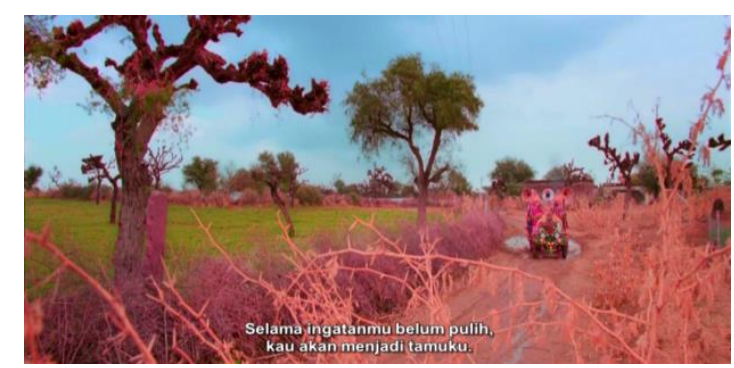

Gambar 3. Bhairon Singh membawa Peekay pulang bersamanya

Berdasarkan cuplikan di atas, dapat disimpulkan bahwa Bhairon Singh memiliki nilai karakter tanggung jawab. la menyadari bahwa ia melakukan kesalahan saat menabrak Peekay sampai Peekay pingsan, ia kemudian membawanya ke klinik, meskipun ia sempat ingin melarikan diri, kemudian ia membawa Peekay ke rumahnya untuk membantu Peekay. Jika Bhairon Singh tidak memiliki nilai tanggung jawab, ia bisa saja meninggalkan Peekay saat ia menabraknya atau saat sedang berada di klinik.

\section{d. Kerja Keras}

Kerja keras adalah tindakan yang menunjukkan upaya sungguh-sungguh dalam menghadapai dan mengatasi berbagai rintangan untuk mencapai tujuan atau menyelesaikan tugas tertentu (Mohamad Mustari). Kerja keras identik dengan sikap pantang menyerah meskipun terkadang mendapatkan perlakuan yang tidak mengenakkan atau gagal dalam satu usaha namun mengulanginya lagi dengan usaha yang lebih baik demi mencapai sesuatu atau menyelesaikan tugas tertentu.

Nilai kerja keras ditunjukkan oleh Peekay hampir di sepanjang cerita film. Peekay yang diutus untuk meneliti kehidupan di bumi kehilangan remot untuk mengendalikan pesawatnya. Sejak saat itu, misinya berubah menjadi misi pencarian remot kontrol. la berusaha untuk memahami kehidupan manusia, mulai dari cara berkomunikasi, berpakaian, kehidupan sosial, hingga beragama. Tidak jarang ia mendapat perlakuan tidak mengenakkan seperti persekusi, masuk penjara, dibohongi, dan lain sebagainya. Salah satu bentuk kerja kerasnya adalah ketika ia pergi dari Mandawa ke Delhi untuk menemukan remotnya. la mulai usahanya dengan menanyakan kepada polisi, namun polisi malah mencemoohnya. Kemudian saat orang-orang mengatakan hanya Tuhan yang dapat "membantu"-nya, 
ia meminta pertolongan kepada Tuhan, meskipun pada awalnya pemahamannya tentang Tuhan dan agama keliru hingga ia harus mengalami persekusi oleh para pengikut agama.

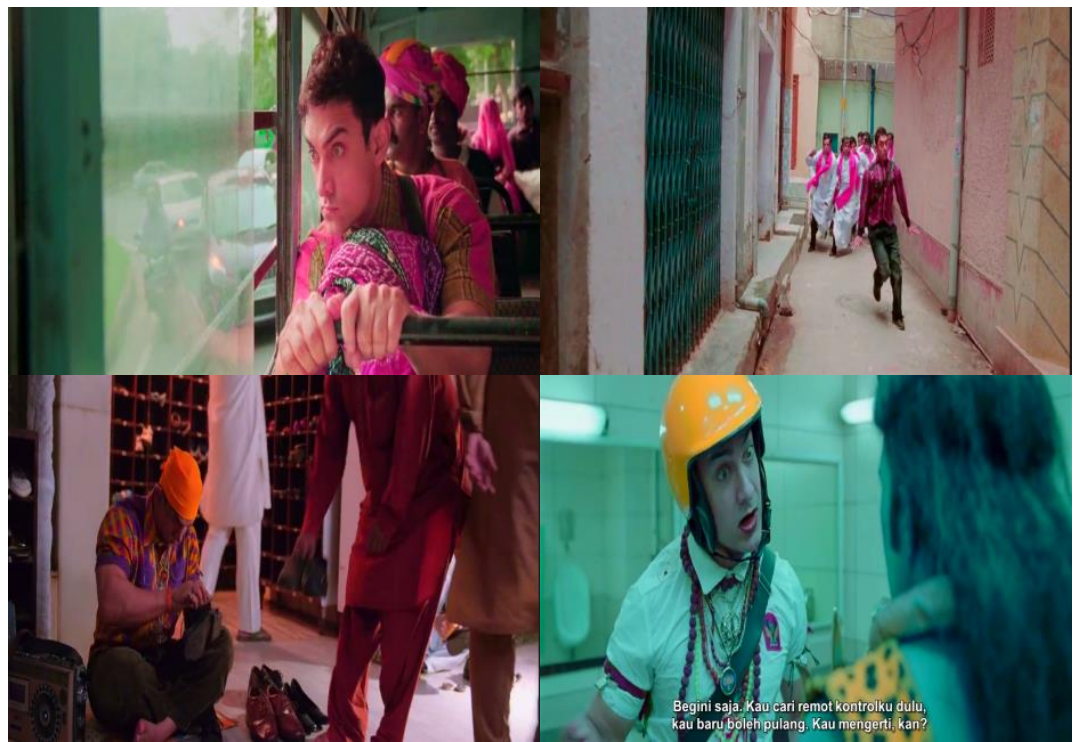

Gambar 4. Peekay berusaha dengan segala cara demi menemukan remotnya

Berdasarkan penjelasan di atas Peekay memiliki nilai kerja keras yang tercermin dari sikapnya yang terus berupaya untuk menemukan remotnya yang hilang. Mulai dari usahanya untuk belajar tentang bagaimana manusia bertahan hidup, cara berbicara, beragama sampai bekerja untuk bertahan hidup di Delhi. Kelakuannya yang aneh tidak jarang membuatnya mendapat perlakuan buruk dari orang lain, namun ia tidak pernah menghiraukan hal tersebut dan tidak membuatnya menyerah hingga akhirnya ia berhasil mendapatkan remotnya kembali. Hal tersebut dikarenakan nilai kerja keras yang dimilikinya demi tujuannya untuk mendapatkan kembali remotnya dan menyelesaikan misi penelitiannya tentang kehidupan di bumi.

\section{e. Pluralis}

Pluralis adalah sikap memberikan respek terhadap berbagai perbedaan yang ada dalam masyarakat baik yang berupa fisik, sifat, adat budaya, suku, dan agama (Mustari, 2014). Nilai pluralis tercermin dari penggambaran negara India yang ada dalam film PK. Dalam suatu dialog, PK menerangkan kepada Jaggu kesannya terhadap keragaman berpakaian yang ada di India.

Jaggu : Dan pakaianmu? Juga mengenakan jeans diduniamu?

Peekay: Tidak, tidak, tidak. Dunia kita tidak mengenakan pakaian apapun. Pertama kali aku tiba disini, kukira orang-orang disini berbeda satu sama lain. Dunia kami dibedakan dari kulit. Di sini ada yang kulitnya bersinar cerah, ada yang kulitnya hitam. Ada yang kulitnya berwarna, ada yang kulitnya polos. Ada yang kulitnya kurus ada juga yang kulitnya ngatung. 


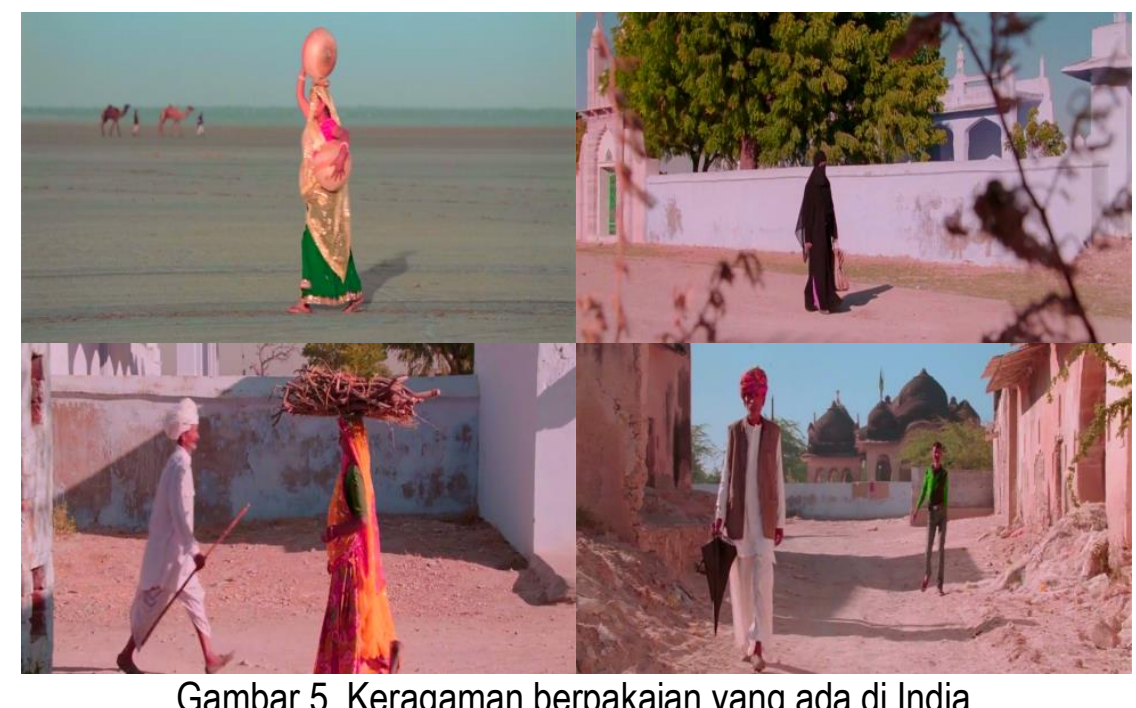

Keragaman berpakaian begitu erat kaitannya dengan pluralis. Sebagaimana yang telah dijelaskan di atas bahwa pluralis adalah keberagaman dalam masyarakat. Setiap kelompok masyarakat baik itu suku maupun agama, memiliki budayanya sendiri dan setiap budaya memiliki tata caranya sendiri termasuk dalam berpakaian. Nilai pluralis yang dapat diambil dari penggambaran Peekay tersebut adalah adanya perbedaan cara mengenakan pakaian dan perbedaan jenis pakaian yang dikenakan setiap kelompok masyarakat di India dan dengan perbedaan tersebut, masyarakat di sana tetap bisa hidup berdampingan secara damai.

\section{f. Suka Menolong}

Menolong adalah kesediaan memberikan bantuan secara sadar dari gerak hatinya. Bantuan tersebut diberikan dalam bentuk apa saja yang memang diperlukan orang yang hendak di tolong baik berupa ucapan, perbuatan, ide, ataupun barang. Nilai suka menolong beberapa kali ditampakkan dalam tayangan film PK seperti ketika PK memberikan uang kepada Jaggu yang tidak memiliki ongkos pulang. Peekay melakukan hal tersebut karena ia merasa sedih setiap kali melihat orang yang tidak bisa pulang ke rumah karena ia merasakan sendiri hal tersebut.

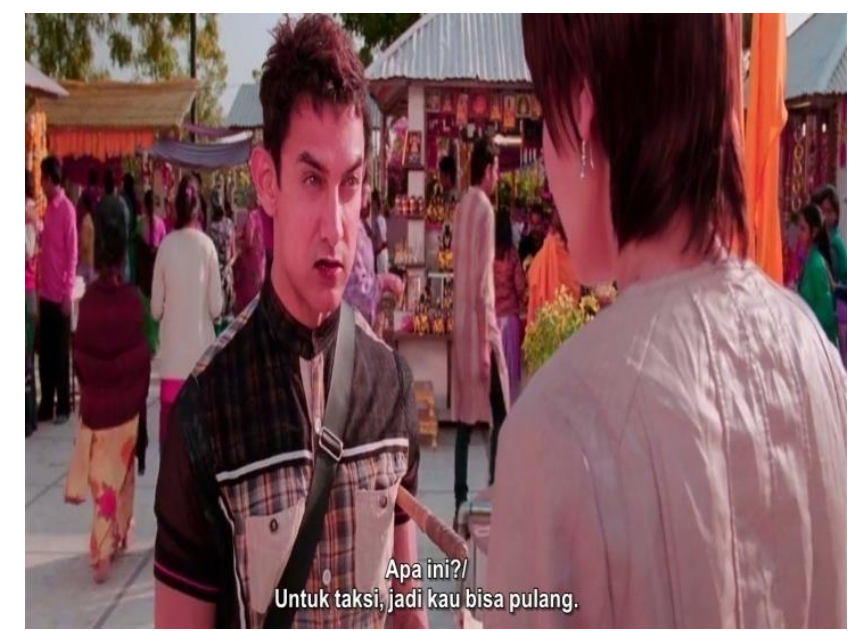

Gambar 6. Peekay memberikan uang kepada Jaggu agar ia bisa pulang

Pada adegan lain, Peekay juga memberikan uang kepada kakek tua yang ingin memberikan kebahagiaan untuk istrinya di hari ulang tahun istrinya tersebut. Tidak hanya itu, ketika sang kakek berniat ingin mengembalikan uang Peekay di kemudian hari, Peekay malah mengatakan tidak perlu untuk mengembalikannya bahkan setelah itu ia memberika uang sekali lagi kepada kakek tersebut. 


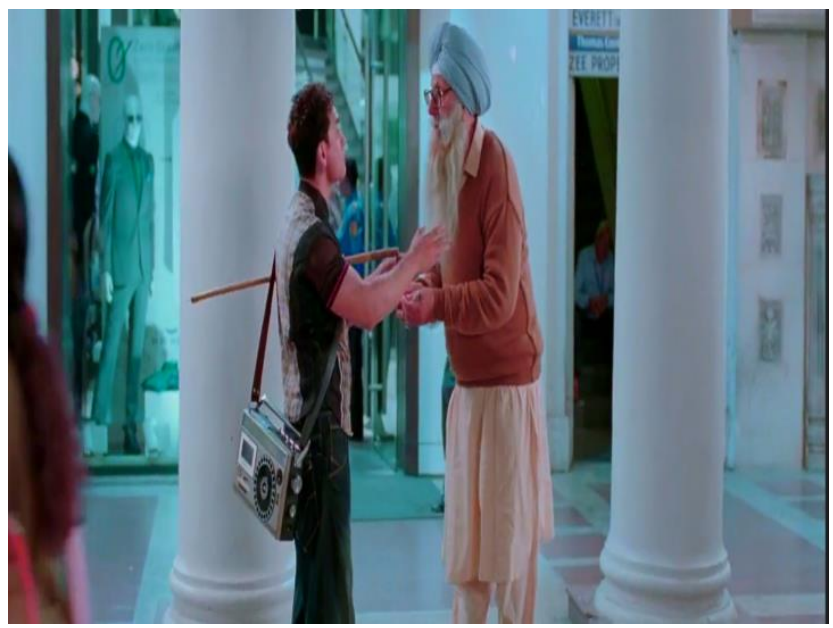

Gambar 7. Peekay memberikan uang kepada seorang kakek

Berdasarkan penjabaran di atas dapat disimpulkan bahwa Peekay memiliki sikap suka menolong. Mustari (2014) menyatakan terdapat tiga alasan mengapa seseorang memberikan pertolongan kepada orang lain, yaitu: 1) teori ongkos hasil, 2) teori empati-altruisme, dan 3) teori evolusi-sosialis. Berdasarkan tiga teori alasan tersebut, penulis mengklasifikasikan alasan Peekay memberi pertolongan kepada Jaggu dan kakek tua tersebud adalah sesuai dengan teori empatialtruisme, dimana ia menolong karena adanya pikiran "ikut merasakan" apa yang dialami orang yang ditolongnya. Ketika ia menolong Jaggu ia merasakan kesulitan ketika seseorang tidak bisa pulang dan ketika menolong kakek tua ia merasakan kesulitan mencari sesuatu.

\section{Relevansi Nilai-Nilai Karakter dalam Film PK dengan Pendidikan Islam}

Pendidikan menjadi sebuah kebutuhan bagi manusia, setiap orang membutuhkan pendidikan untuk mengembangkan segala potensi yang dimilikinya. Kurniawan (2017) memberikan definisi bahwa pendidikan adalah segala aktivitas atau upaya yang secara sadar dilakukan oleh seorang individu sebagai pendidik kepada individu-individu lain sebagai peserta didik terhadap seluruh aspek perkembangan kepribadian, baik jasmani maupun rohani secara formal, informal, dan nonformal yang terjadi secara terus menerus demi mencapai kebahagiaan dan nilai yang tinggi. Tujuan utama dalam pendidikan selaain untuk mencerdaskan manusia adalah juga untuk membuat manusia tersebut memiliki karakter yang baik. Tujuan tersebut sama halnya dengan pendidikan Islam. Hal tersebut senada dengan pernyataan Marzuki (2019) yang menyebut bahwa pendidikan karakter merupakan roh ataupun inti dari pendidikan Islam.

Setelah mendeskripsikan nilai-nilai karakter yang terdapat dalam film PK, kali ini penulis akan mencari relevansi antara nilai-nilai tersebut dengan pendidikan Islam. Pendidikan Islam menurut Mujib (2010) memuat tiga nilai normatif yang dijadikan sebagai acuan, yaitu nilai l'tiqadiyyah, Khuluqiyyah, dan Amaliyyah. Sementara itu Majid \& Andayani menyebut ada dua nilai dasar dalam pendidikan Islam yaitu nilai Ilahiyah dan nilai Insaniyah. Nilai I'tiqadiyyah atau nilai Ilahiyah berkaitan pendidikan keimanan dan keyakinan, nilai tersebut memiliki relevansi dengan nilai karakter religius dalam film PK. Ketika Peekay berdebat dengan Tapasvi di acara TV, Peekay menyatakan keyakinannya akan eksistensi Tuhan, ia mengatakan bahwa dengan meyakini Tuhan, manusia menjadi memiliki harapan dan kekuatan.

Selanjutnya nilai Khuluqiyyah atau nilai Insaniyah yang berkaitan langsung dengan karakter. Nilai Khuluqiyyah atau nilai Insaniyah dalam pendidikan Islam sejalan dengan nilai-nilai karakter dalam film PK seperti nilai karakter jujur dan tanggung jawab, kejujuran dan tanggung jawab dalam Islam relevan dengan sikap al amanah atau sikap dapat dipercaya yang berlawanan dengan sifat al khiyanah, sikap 
al amanah tersebut juga menjadi salah satu sifat wajib untuk para rasul dalam ajaran Islam. Selanjutnya, nilai karakter kerja keras, dalam Islam kerja keras atau berusaha disebut juga dengan ikhtiar. Selain diwajibkan untuk berdo'a meminta pertolongan kepada Allah serta tawakal atau berserah diri, seseorang juga perlu melakukan usaha atau ikhtiar untuk mencapai tujuan tertentu. Berikutnya nilai pluralis, dalam Islam nilai pluralis disebut dengan al musawah, yaitu pandangan bahwa semua manusia sama dalam harkat dan martabatnya tanpa memandang jenis kelamin, kebangsaan, ataupun kesukuannya. Seluruhnya bersaudara, baik itu saudara melalui iman, maupun saudara antar sesama manusia. Nilai suka menolong juga memiliki relevansi dengan nilai yang ada dalam pendidikan Islam yaitu al munfiqun yaitu sikap yang memiliki kesediaan untuk menolong sesama manusia terutama yang membutuhkan atau kurang beruntung.

\section{KESIMPULAN}

Karakter adalah tujuan utama dalam pendidikan, bangsa yang maju adalah bangsa yang memiliki karakter yang baik. Nilai-nilai karakter dapat didapat dari berbagai media, salah satunya adalah media film. Film selain memiliki fungsi sebagai media hiburan, juga dapat dimanfaatkan sebagai media pembelajaran, dalam hal ini untuk menginternalisasi nilai-nilai karakter. Film PK adalah salah satunya. Hal tersebut dikarenakan dalam film ini terdapat berbagai nilai-nilai karakter. Nilai-nilai karakter tersebut seperti nilai religius, jujur, tanggung jawab, kerja keras, pluralis, dan suka menolong. Nilai karakter religius dalam film PK memiliki relevansi dengan nilai I'tiqadiyyah atau nilai Ilahiyah dalam pendidikan Islam sementara nilai karakter jujur, tanggung jawab, kerja keras, pluralis, dan suka menolong memiliki relevansi dengan nilai Khuluqiyyah atau nilai Insaniyah dalam pendidikan Islam. Penelitian ini menunjukkan bahwa film selain sebagai media hiburan, juga mengandung nilai-nilai karakter yang dapat digunakan sebagai media pembelajaran. Dari hasil penelitian ini diharapkan dapat menjadi referensi serta inspirasi untuk penelitian selanjutnya.

\section{SARAN}

Film selain sebagai media hiburan, juga dapat dimanfaatkan sebagai media pembelajaran, baik secara formal maupun nonformal. Penonton film hendaknya mampu memetik setiap pembelajaran dalam film yang menjadi tontonan kemudian menginternalisasikannya ke dalam diri serta menampilkannya ke dalam perilaku sehari-hari.

Untuk penelitian selanjutnya hendaknya melakukan kajian lebih lanjut tentang film-film yang dianggap sebagai media hiburan tetapi juga memiliki kandungan nilai-nilai pendidikan tertentu untuk diterapkan sebagai media pembelajaran pada mata ajar tertentu.

\section{DAFTAR PUSTAKA}

Hidayatulloh, M., Agung. (2017). Nilai-Nilai Pendidikan Karakter untuk Anak Usia Dini dalam Film Adit \& Sopo Jarwo. Thufula Jurnal Inovasi Pendidikan Guru Raudhatul Athfal. 5(1)42-63, DOI: 10.21043/thufula.v5i1.2345 diakses pada 3 Oktober 2019.

Kurniawan, Syamsul. (2017). Pendidikan Karakter. Yogyakarta: Ar-Ruzz Media.

Majid, Abdul \& Andayani, Dian. (2017). Pendidikan Karakter Perspektif Islam. Bandung: Remaja Rosdakarya.

Marzuki. (2019). Pendidikan Karakter Islam. Jakarta: Amzah.

Mujib, Abdul. (2010). IImu Pendidikan Islam. Jakarta: Kencana. 
Muslich, Masnur. (2018). Pendidikan Karakter: Menjawab Tantangan Krisis Multidimensional. Jakarta: Bumi Aksara.

Mustari, Mohamad. (2014). Nilai-Nilai Karakter. Jakarta: Rajawali Pers.

Riyaningsih, Etik., Maryono., Harini. (2018). Pembentukan Karakter Bagi Peserta Didik Sekolah Menengah Atas Dalam Pembelajaran Seni Tari Melalui Model Discovery Learning. Teknodika Jurnal Penelitian Teknologi Pendidikan. 16(2)44-52, DOI: https://doi.org/10.20961/teknodika.v16i2.34778 diakses 24 Oktober 2019.

Rohmat. (2016). Memelihara Kualitas Proses Belajar Mengajar Berbasis Media. Surakarta: Gerbang Media.

Samani, Muchlas. \& Hariyanto. (2017). Pendidikan Karakter. Bandung: Remaja Rosdakarya.

Sukmadinata, Nana Syaodih. (2012). Metode Penelitian Pendidikan. Bandung: Remaja Rosdakarya.

Suryani, Nunuk., Setiawan Achmad., \& Putria, Aditin. (2018). Media Pembelajaran Inovatif dan Pengembangannya. Bandung: Remaja Rosdakarya.

Wibowo, E. (2019). Relevansi Pendidikan Karakter Dalam Film Kungfu Panda Terhadap Pendidikan Agama Islam. Raushan Fikr Jurnal IImiah Mahasiswa. 7(2)131-156, DOI: https://doi.org/https://doi.org/10.24090/jimrf.v7i2.25144 diakses 28 Agustus 2019

Widyatmaka, W., Sulistyo E., \& Nugroho, S. (2019). Nilai Pendidikan Karakter Pada Film Sang Kiai. Mudra Jurnal Seni Budaya. 34(1)73-79, DOI: https: //doi.org/10.31091/mudra.v34i1.639 diakses 28 Agustus 2019. 